\title{
Tripterygium wilfordii (Celastraceae): A new generic and species record for the flora of Vietnam
}

\author{
Do Van HAI ${ }^{1,2}$, Bui Hong QUANG ${ }^{1,2}$, Tran The BACH ${ }^{1,2}$, Tran Duc BINH ${ }^{1}$, \\ Ritesh Kumar CHOUDHARY ${ }^{3}$ and Joongku LEE* \\ ${ }^{l}$ Department of Botany, Institute of Ecology and Biological Resources, Vietnam Academy of Science and Technology, Hanoi, Vietnam \\ ${ }^{2}$ Graduate University of Science and Technology, Vietnam Academy of Science and Technology, Hanoi, Vietnam \\ ${ }^{3}$ Biodiversity \& Palaeobiology Group, Agharkar Research Institute, Pune 411 004, India \\ ${ }^{4}$ Department of Environment and Forest Resources, Chungnam National University, Daejeon 34134, Korea
}

(Received 12 July 2021; Revised 25 August 2021; Accepted 9 September 2021)

\begin{abstract}
Tripterygium wilfordii Hook.f. (Celastraceae), collected from Phia Oac-Phia Den National Park of Vietnam, is reported here as a new generic and species record for the flora of Vietnam. The genus Tripterygium differs from other genera of Celastraceae by its samara fruits, which become three-winged at maturity, and a scandent shrub. Taxonomic notes, descriptions, line drawing and photographs are provided, together with short notes on the distribution, ecology and phenology of Tripterygium wilfordii.
\end{abstract}

Keywords: protected area, Phia Oac-Phia Den, floristic diversity, range extension

The Celastraceae (Brown, 1814: 554) family of angiosperms consists of almost 100 genera and approximately 1,350 species (Simmons, 2004) in the world. Southeast Asia is one of the main centres of diversity of the family. A recent checklist of Celastraceae in Vietnam documented 13 genera and about 80 species under the family (Ban, 2003). Thereafter, several new genera and species were documented for the family in Vietnam (Simmons, 2004; Chinh et al., 2016; Savinov et al., 2018, 2019), taking the total count to 16 genera and about 83 species in the country.

Phia Oac-Phia Den National Park of the Cao Bang province in northern Vietnam shares its border with China, and known for its rich biodiversity (Fig. 1). Being located at the intersection of the tropical and subtropical climatic zones, the National Park provides a suitable habitat for many interesting flora and fauna. In 2016, we made a floristic survey of this area, and collected an interesting plant species. After a thorough scrutiny of the taxonomic literature and type specimens housed in several herbaria (HN, HNU, K, P, VNM), the collected species was identified as Tripterygium wilfordii Hook.f. which was never reported from Vietnam. Tripterygium wilfordii was described by Hooker (1862), based on the material collected by Wilford in 1858 from Taiwan (Formosa). Presently, the genus Tripterygium is known by only four species in the world, i.e. T. doianum, T. hypoglaucum, T. regelii, and $T$. wilfordii (POWO, 2021). However, their traditional morphological circumscription remains in question. Some recent studies vouched for their delimitation to a single species exhibiting extreme variation in their morphology (Ma et al., 1999; Simmons, 2004). There have been conflicting view points of the taxonomists based on their treatments based on morphological and molecular data. Ma and Funston (2008) pointed out the difficulty to distinguish Tripterygium hypoglaucum and T. regelii based on morphological data and they synonymized them under $T$. wilfordii. The molecular studies conducted by Law et al. (2011) did not consider $T$. hypoglaucum and T. doianum distinct from $T$. wilfordii. The study also recognised $T$. regelii as a distinct species. In the molecular study conducted by Ma et al. (2017), T. wilfordii and T. hypoglaucum clustered together and did not appear as distinct lineages, while $T$. regelii nested out as a separate cluster. Authors of the present work also believe that $T$.

\footnotetext{
*Author for correspondence: joongku@cnu.ac.kr
} 


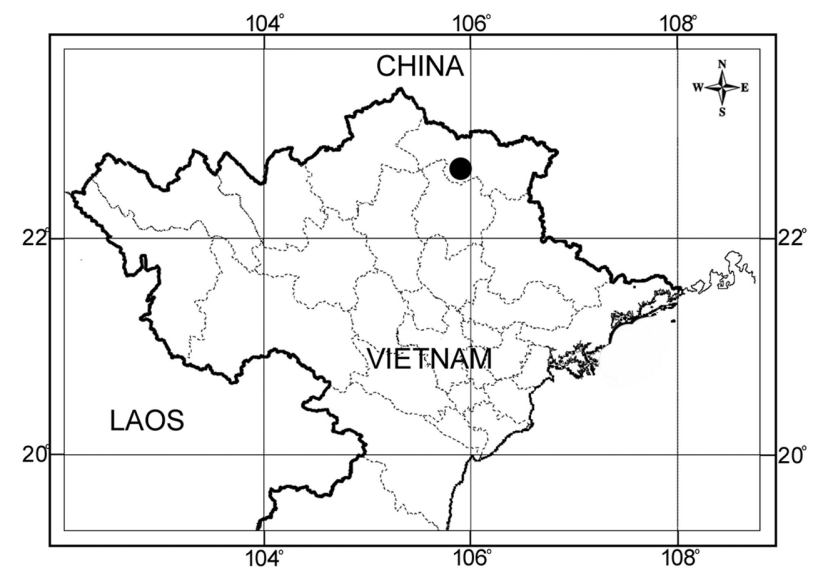

Fig. 1. Distribution map of Tripterygium wilfordii in northern Vietnam.

hypoglaucum is conspecific with $T$. wilfordii, while $T$. regelii deserves a distinct species status.

The genus Tripterygium clearly differs from other Celastraceae genera in Vietnam by having three lateral winged samaras in contrast to the other genera having drupe, berry, and capsule types of fruits. The genus was hitherto known to occur in China, Japan, Korea, and Myanmar (Simmons, 2004). The present report is a new distributional record of this genus in Vietnam. We provide a description, line drawing and colour photographs of Tripterygium wilfordii, with an updated key to the genera of Celastraceae in Vietnam for easy identification.

\section{Materials and Methods}

The newly recorded species was collected during an expedition by the scientists from Vietnam and Korea in the Phia Oac-Phia Den National Park in Vietnam during June 2016. The specimens collected from the natural habitats were thoroughly processed using standard herbarium techniques (Jain and Rao, 1977) and deposited in the Herbarium of Institute of Ecology \& Biological Resources (HN) Vietnam and Chungnam National University, Korea. Morphological characters were studied consulting the relevant literature (Hou, 1962; Lu and Yang, 1993; Cheng, 1999; Ma et al., 1999; Ho, 2000; Simmons, 2004; Ma and Funston, 2008). The specimens of Tripterygium and allied genera kept in different herbaria of Vietnam such as Herbarium of Institute of Ecology and Biological Resources (HN), VNU University of Science (HNU), Institute of Tropical Biology (VNM) were studied. Photographs of the specimens housed in the virtual herbaria such as $\mathrm{K}$, $\mathrm{P}$ were also studied.

\section{Taxonomic Treatment}

Tripterygium Hook.f. in Benth. \& Hook.f., Gen. P1. 1: 368, 1862.-TYPE: Tripterygium wilfordii Hook.f.

Scandent shrubs or sometimes semi-woody vines, glabrous or tomentose; branchlets sometimes 4-6-angled. Leaves alternate, serrate, stipulate. Inflorescence axillary or terminal, thyrsoid. Flowers bisexual or unisexual (polygamous), 5merous. Disk fleshy, cupuliform, 5-lobed, intrastaminal; anthers longitudinally dehiscent, introrse. Ovary 3-locular; ovules erect, 2 per locule. Samara 3-winged, chartaceous. Seed 1, trigonous, albuminous.

Distribution: China, Japan, Korea, Taiwan (Simmons, 2004), and Vietnam.

Tripterygium wilfordii Hook.f. in Benth. \& Hook.f., Gen. Pl. 1: 368, 1862 (Figs. 2, 3).-TYPE: Taiwan. NW Formosa, June 1858, C. Wilford 484 (Lectotype or possibly holotype, K, [2 sheets], K000478771, K000478770, photos! [Turner, 2016]).

Aspidopterys hypoglauca H. Lév., Repert. Spec. Nov. Regni Veg. 9: 458, 1911; Tripterygium hypoglaucum (H. Lév.) Hutchins., Bull. Misc. Inform. Kew: 101, 1917.-TYPE: China. Kouy-Tcheou (Guizhou), Ma-Jo, J. Cavalerie 3316 (photo, https://plants.jstor.org/search).

Deciduous subshrubs, or scandent and scrambling, or sometimes semi-woody vines, $2-4 \mathrm{~m}$; branching distally, slender or scrambling, minutely pubescent when young or in open sunlight, becoming glabrous when old or in shade, slightly angled, verrucose or not. Stipules linear, caducous. Leaves simple; petiole $1-1.5 \mathrm{~cm}$; blade usually ovate or rounded-ovate, sometimes oblong or elliptic-ovate, 5-8 $\times 3$ $6 \mathrm{~cm}$, papery, leathery, glabrous or sparsely scurfy tomentose with reddish brown hairs, abaxially \pm farinose, base broadly cuneate, or rounded to cordate, margin entire or less often crenulate, apex short to long acuminate or acute, tip often blunt. Thyrses large, composed of several to dozens of thyrslets, 10 $15 \times 4-8 \mathrm{~cm}$; flowers 1 normal and 1 unfertilized male. Flowers whitish, greenish, or yellow-green, small, 4-6 $\times 4-6 \mathrm{~mm}$; calyx 5-lobed, hemispheric, ca. $1 \mathrm{~mm}$; petals 5, oblong to subovate, slightly narrowed to base, $2-2.5 \mathrm{~mm}$, apex rounded; stamens 5 , inserted at margin of cup-shaped and compressed disk; disk bright green, fleshy, ca. $2 \mathrm{~mm}$ in diam; ovary superior, 3-edged, combined with disk at base, incompletely 3-locular, with 3 prominent ca. $1 \mathrm{~mm}$ lobes, short style at apex; stigma 


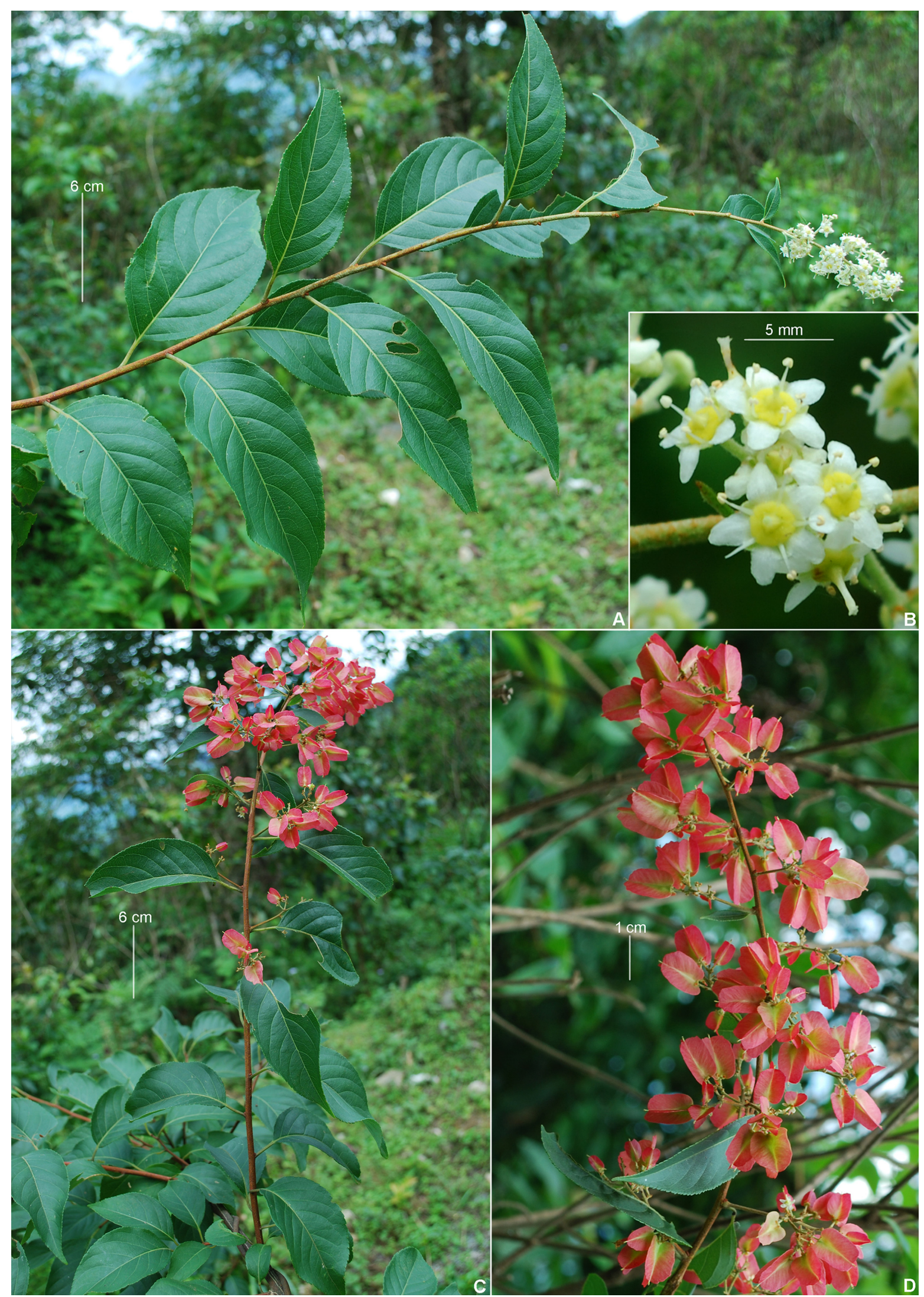

Fig. 2. Tripterygium wilfordii Hook.f. A. Branchlet with inflorescence. B. A part of the inflorescence. C. Branchlet with infructescence. D. Fruits. 


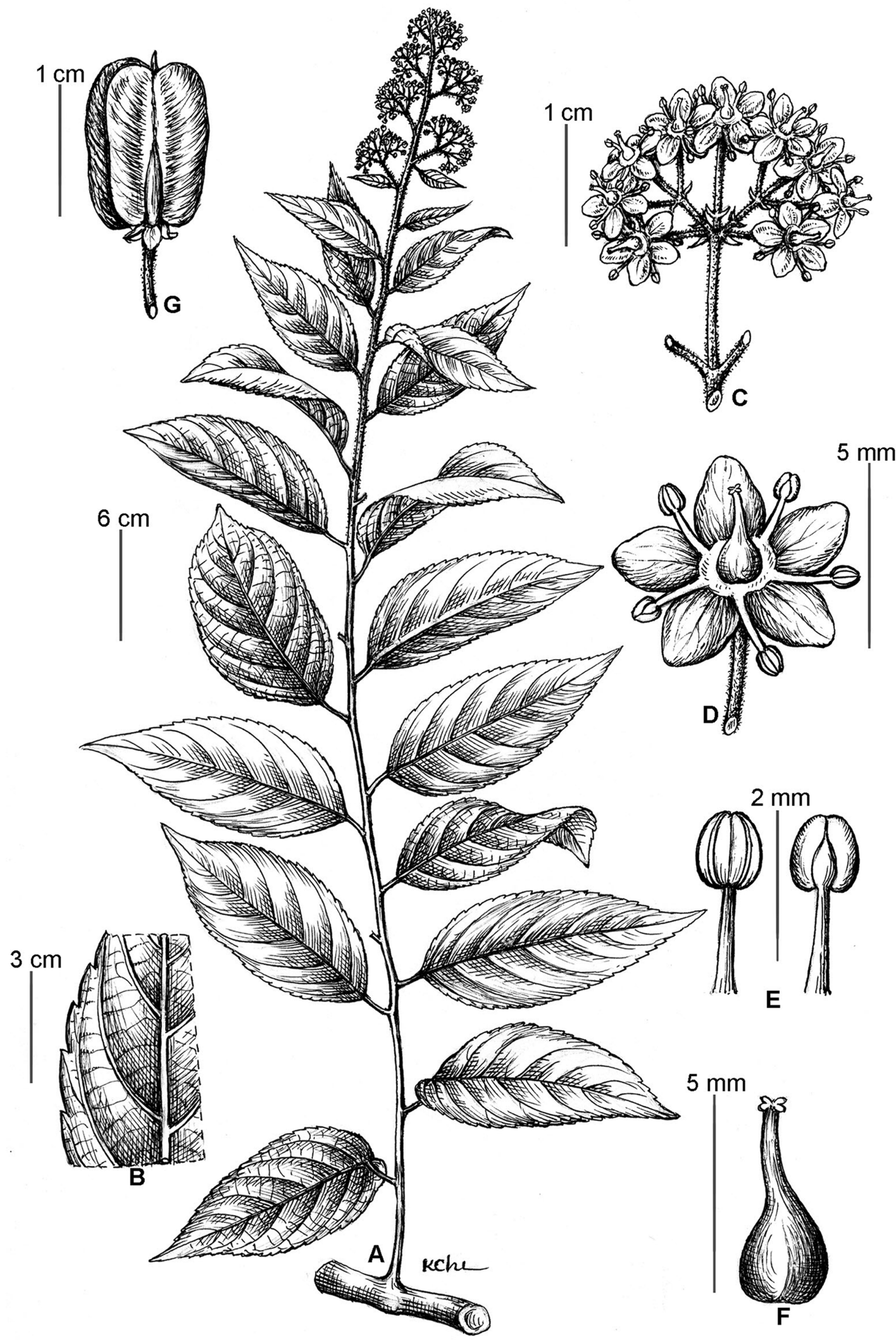

Fig. 3. Tripterygium wilfordii Hook.f. A. Branchlet with inflorescence. B. A part of leaf. C. A part of inflorescence. D. Flower. E. Stamen. F. Ovary and style. G. Fruit (Line drawing by Ms. Le Kim Chi). 
capitate, bright purple. Samara usually green or greenish brown when mature, sometimes pink or pinkish purple, 1.5-2.0 × 1.0$1.5 \mathrm{~cm}$. Seed compressed, 3-angled, ca. $5 \times 1.5-3 \mathrm{~mm}$.

Flowering and fruiting: May to October.

Distribution: Vietnam: Cao Bang Province, Nguyen Binh District, Quang Thanh commune. China, Japan, Korea, Myanmar and Taiwan.

Ecology and habitat: Tripterygium wilfordii was found growing along the roadside forest margins at about $1,122 \mathrm{~m}$ above sea level.

Specimens examined: VIETNAM. Cao Bang Province: Nguyen Binh district, Quang Thanh commune, Phia Oac-Phia Den National Park, 29 June 2016, near 22 $37^{\prime} 32.0^{\prime \prime} \mathrm{N}, 105^{\circ}$ 52' 52.4"E; 1,122 m a.s.1., T. T. Bach, V. T. Chinh, D. V. Hai, D. H. Son, T. D. Binh, Joongku Lee, Sang-Jin Lee, Donghyeong Kwak, Hyun Jae Cho, HNCNU 318 (HN, herbarium of Chungnam National University).
Tripterygium wilfordii is currently known from one locality in Nguyen Binh District of Cao Bang Province of North Vietnam: Quang Thanh Commune. The plant grows along the road, forest margins of secondary evergreen broad-leaved forest in association with Antidesma bunius, Boenninghausenia albiflora, Mallotus barbatus, Saurauia rubricalyx, and Trema tomentosa at an elevation of 1,100-1,200 m a.s.l. During our investigation, we could find only one population growing under secondary forests. Therefore, the information currently obtained is inadequate to assess the species risk of extinction, whether direct or indirect. Further field investigation is needed, and it is expected that the species may be found in other localities from Vietnam. In accordance to the IUCN Red List Categories (2012, ver 3.1), we propose a temporary listing of this species as a taxon under the Data Deficient (DD) category.

\section{Key to the genera of Celastraceae in Vietnam}

(partly based on Hou, 1962; Hou et al., 2010; Simmons, 2004)

1. Stamens numerous

1. Plagiopteron

1. Stamens $2-5$.

2. Disk intrastaminal or stamens on disk; flowers unisexual or bisexual; fruit drupaceous, baccate, samaroid, or capsular; seeds with or without surrounding wings, arillate or exarillate.

3. Plants unarmed.

4. Leaves alternate on mature stems.

5. Leaves with reticulate secondary venation, petiole not geniculate.

6. Ovary with terminal style; stamens not alternating with staminodes; fruit dehiscent or indehiscent, not drupe with numerous stones.

7. Fruit capsular; ovules 1-12 per locule.

8. Scandent shrubs; inflorescence terminal or axillary, thyrsoid, cymose, or flowers solitary; flowers unisexual, rarely bisexual, dioecious; ovules 1-2 per locule; arils nearly enveloping seeds

2. Celastrus

8. Erect or scandent trees or shrubs; inflorescence axillary, rarely terminal, cymose, fasciculate, or flowers solitary; flowers bisexual, rarely unisexual; monoecious or dioecious; ovules 1-12 per locule; arils basal to enveloping seeds

3. Maytenus

7. Fruit samaroid; ovules 1-2 per locule

4. Tripterygium

6. Ovary with apical hollow and style-like central column arising from base of hollow; stamens alternating with small staminodes; drupe with numerous stones

5. Siphonodon

5. Leaves with distinct crossbar secondary venation, petiole distally geniculate

6. Bhesa

4. Leaves decussate or opposite.

9. Petals slightly united at the base. Disk proper absent, filaments united at the base in a ring or short tube, by some interpreted to represent a disk, usually united with the petals

7. Microtropis

9. Petals free. Disk conspicuous, fleshy, cupular or flat, free from the petals.

10. Ovary 3-, or 4-5 celled. Ovules $1-18$ in each cell.

11. Ovary 4-5 celled.

12. Ovules 2 in each cell

8. Euonymus 
12. Ovule 1 in each cell

11. Ovary 3-celled. Ovules (4-6) 8-18 in each cell

10. Ovary 2-celled, or 1-celled by abortion. Ovules 2 in each cell.

13. Disk more or less flat. Anthers subglobose and rounded at the apex, connective invisible on the dorsal side

11. Cassine

13. Disk cupular. Anthers ovoid and short-apiculate, connective distinct and broad on the dorsal side *.

12. Pleurostylia

3. Plants with thorns or stems terminating in sharp points

13. Gymnosporia

2. Disk extrastaminal; flowers bisexual; fruit baccate with seeds surrounded by mucilaginous arils, transversely-flattened, trilobed capsules with seeds with membranous basal wings or narrow stipes, or capsules that are circular or trigonous in cross section with seeds with membranous apical wings or arils basal to partially enveloping seeds.

14. Fruit baccate with seeds surrounded by mucilaginous arils

14. Salacia

14. Fruit transversely-flattened, trilobed capsules with seeds with membranous basal wings or narrow stipes, or capsules that are circular or trigonous in cross section.

15. Ovules 2 per locule

15. Reissantia

15. Ovules 3-22 per locule

16. Loeseneriella

ORCID: Do Van Hai https://orcid.org/0000-0001-7841-0585; Bui Hong Quang https://orcid.org/0000-0001-6878-7514; Tran The Bach https://orcid.org/0000-0003-3798-5969; Tran Duc Binh https://orcid.org/0000-0001-6658-0739; Ritesh Kumar Choudhary https://orcid.org/0000-0001-6250-4624; Joongku Lee https://orcid.org/0001-0001-6250-3138

\section{Acknowledgments}

Authors are grateful to the curators of herbaria HN, VNM, and HNU. This research was supported by the Bio \& Medical Technology Development Program of the National Research Foundation (NRF), South Korea funded by the Korean government (MSIT) (NRF-2017M3A9A507020221). The fourth author (RKC) thanks the Director, Agharkar Research Institute for facilities and encouragements.

\section{Conflict of Interest}

The authors declare that there are no conflicts of interest.

\section{Literature Cited}

Ban, N. T. 2003. Celastraceae. In Checklist of Plant Species of Vietnam, Vol. 2. Ban, N. T. (ed.), Agricultural Publishing House, Hanoi. Pp. 1120-1134. (in Vietnamese).

Brown, R. 1814. Celastraceae. In A Voyage to Terra Australis 2. Flinders, M. (ed.), W. Bulmer and Co., Cleveland-Row, London. P. 554

Cheng, C. Y. 1999. Tripterygium. In Flora Republicae Popularis Sinicae 45(3). Cheng C. Y. and P. H. Huang (eds.), Science
Press, Beijing. Pp. 178-181. (in Chinese)

Chinh, V. T., R. K. Choudhary, T. T. Bach, B. H. Quang, D. V. Hai, S. Eum and J. Lee. 2016. Morphological and anatomical studies of the newly recorded genus Plagiopteron Griff. (Celastraceae) from Vietnam. Bangladesh Journal of Plant Taxonomy 23: 161-166.

Ho, P. H. 2000. Celastraceae. In Cây Cỏ Việt Nam 2. Tre Publishing House, Ho Chi Minh. Pp. 142-162. (in Vietnamese)

Hooker, J. D. 1862. Tripterygium. In Genera Plantarum ad Exempla Imprimis in Herbariis Kewensibus Servata Definita, Vol. I, Pars I. Bentham, G. and J. D. Hooker (eds.), London. P. 368.

Hou, D. 1962. Celastraceae. In Flora Malesiana, Ser. I, 6(2). Van Steenis, C. G. G. J. (ed.), Wolters-Noordhoff Publishing, Groningen. Pp. 227-291.

Hou, D., I. A. Savinov and P. C. Van Welzen. 2010. Celastraceae. In Flora of Thailand, Vol. 10(2), Santisuk, T. and K. Larsen (eds.), Prachachon Co. Ltd., Bangkok. Pp. 141-198.

IUCN. 2012. IUCN Red List Categories and Criteria. Version 3.1. 2nd ed. IUCN, Gland and Cambridge, $32 \mathrm{pp}$.

Jain, S. K. and R. R. Rao. 1977. A Handbook of Field and Herbarium Methods. Today and Tomorrow. Printers and Publishers, New Delhi, 157 pp.

Law, S. K.-Y., M. P. Simmons, N. Techen, I. A. Khan, M.-F. He, P.-C. Shaw and P. P.-H. But. 2011. Molecular analyses of the Chinese herb Leigongteng (Tripterygium wilfordii Hook. f.). Phytochemistry 72: 21-26.

Lu, S. Y. and Y. P. Yang. 1993. Celastraceae. In Flora of Taiwan, 2nd ed. Vol. 3. National Science Council of the Republic of China, Taipei. Pp. 640-660.

Ma, B., T. Hu, P. Li, Q. Yuan, Z. Lin, Y. Tu, J. Li, X. Zhang, X. Wu, X. Wang, L. Huang and W. Gao. 2017. Phylogeographic 
and phylogenetic analysis for Tripterygium species delimitation. Ecology and Evolution 7: 8612-8623.

Ma, J.-S., A. R. Brach and Q.-R. Liu. 1999. A revision of the genus Tripterygium (Celastraceae). Edinburgh Journal of Botany 56: 33-46.

Ma, J. S. and A. M. Funston. 2008. Tripterygium. In Flora of China, Vol. 11. Oxalidaceae through Aceraceae. Wu, Z. Y., P. H. Raven and D. Y. Hong (eds.), Science Press, Beijing and Missouri Botanical Garden, St. Louis, MO. Pp. 486-487.

POWO (Plants of ther World Online). 2021. Tripterygium. Retrieved Jul. 2, 2021, available from http://plantsoftheworld online.org.

Savinov, I. A., M. S. Nuraliev, N. A. Vislobokov, B. Pan, F. Wen,
L.-F. Fu, Y.-G. Wei and L. V. Averyanov. 2018. Lectotypification and new data on distribution of Glyptopetalum sclerocarpum (Celastraceae). Phytotaxa 350: 33-41.

Savinov, I. A., M. S. Nuraliev, A. N. Kuznetsov, S. P. Kuznetsova, H. T. Luu, H. D. Tran and H. T. Luong. 2019. Microtropis cerocarpa (Celastraceae), a new species from southern Vietnam. Phytotaxa 387: 140-148.

Simmons, M. P. 2004. Celastraceae. In The Families and Genera of Vascular Plants. Vol. 6. Kubitzki, K. (ed.), Springer-Verlag, Berlin. Pp. 29-64.

Turner, I. M. 2016. Species names attributed to Bentham \& Hooker's Genera Plantarum. Annales Botanici Fennici 53: 285-337. 